\title{
The influence of green microstructure and sintering parameters on precipitation process during copper-nickel-zinc ferrites sintering
}

\author{
ANTONIO BARBA*, CAROLINA CLAUSELL, JUAN CARLOS JARQUE AND MARÍA MONZÓ
}

Departamento de Ingeniería Química. Instituto Universitario de Tecnología Cerámica, Universitat Jaume I, 12071 Castellón, Spain

\begin{abstract}
Microstructural changes that occur during heat treatment of copper-nickel-zinc ferrites have been studied. The process of precipitation of the two types of crystals that occur during the sintering process has been analyzed. It is found that this process depends on dry relative density of the press specimens and on the following sintering parameters: sintering temperature, sintering time and cooling rate of the thermal cycle. Crystal precipitates characterization have been done by scanning electron microscopy (SEM), energy-dispersive X-ray (EDX) analysis, X-ray diffraction (XRD), and X-ray photoelectron spectroscopy (XPS). These techniques have allowed to determine the nature of these crystals, which in this case correspond to zinc and copper oxides. It has been used two chemical reactions to explain the bulk precipitation and subsequent re-dissolution of these crystal precipitates during sintering.
\end{abstract}

Keywords: copper-nickel-zinc ferrites, sintering, microstructure, precipitation, zinc oxide, copper oxide.

Influencia de la microestructura en verde y de las variables de sinterización en el proceso de precipitación producido durante la sinterización de ferritas de cobre-níquel-cinc

En este trabajo se han estudiado los cambios microestructurales que se producen durante el tratamiento térmico de las ferritas de cobre-níquel-cinc y se ha analizado el proceso de precipitación de los dos tipos de cristales que aparecen durante el proceso de sinterización. Se ha encontrado que este proceso depende de la densidad relativa en seco de las muestras compactadas y de las siguientes variables de la etapa de sinterización: temperatura y tiempo de sinterización y velocidad de enfriamiento. La caracterización de los cristales precipitados se ha realizado por microscopía electrónica de barrido (MEB), microanálisis por dispersión de energía de rayos X (EDX), difracción de rayos X (DRX), y espectroscopía de fotoelectrones de rayos X (XPS). Estas técnicas han permitido determinar la naturaleza de estos cristales, que en este caso corresponden a los óxidos de cinc y de cobre. Se han propuesto dos reacciones químicas que permiten explicar el proceso de precipitación y la posterior re-disolución de estos cristales precipitados durante la sinterización de las muestras.

Palabras clave: ferritas de cobre-níquel-cinc, sinterización, microestructura, precipitación, óxido de cinc, óxido de cobre.

\section{INTRODUCTION}

Ferrite powders containing nickel and zinc and different amounts of copper are typically used as electromagnetic wave absorbers. Previous papers by the present authors ${ }^{1-4}$ addressed the synthesis, sintering, and properties of copper-nickel-zinc ferrites, and a thermal cycle based on sintering kinetics was established ${ }^{2-4}$. The magnetic properties of these materials are not only determined by their chemical composition but also by their microstructure, i.e. grain- and pore-size distribution, total porosity (or relative density), and grain-boundary characteristics ${ }^{5-9}$.

In this paper the authors studied crystal precipitation process during the sintering of copper-nickel-zinc ferrites,

\footnotetext{
* Author to whom correspondence should be addressed. e-mail: barba@qui.uji.es
} 
determining the nature of the $\mathrm{Zn}$ - and $\mathrm{Cu}$-containing crystal precipitates and explaining the bulk precipitation and subsequent re-dissolution of the zinc and copper oxides by using two consecutive chemical reactions proposed in a previous paper $^{10}$. The relationship between the occurrence of crystal precipitates and four variables (dry relative density, sintering temperature, sintering time and cooling rate) is also established in order to avoid crystal precipitate formation during sintering or dissolve the crystal precipitates in the cooling stage of the thermal cycle.

\section{EXPERIMENTAL PROCEDURE}

\subsection{Material preparation}

A commercial spray-dried copper-nickel-zinc ferrite powder, supplied by Fair-Rite Products Corp., was used as raw material. The chemical composition of the ferrite powder was experimentally determined by X-ray fluorescence (FRX) to be $65.9 \mathrm{wt} \% \mathrm{Fe}_{2} \mathrm{O}_{3}, 23.1 \mathrm{wt} \% \mathrm{ZnO}, 6.9 \mathrm{wt} \% \mathrm{NiO}$, and $4.1 \mathrm{wt} \%$ $\mathrm{CuO}$. The true density of the ferrite powder was experimentally determined on a helium pycnometer to be $5380 \mathrm{~kg} / \mathrm{m}^{3}$.

The ferrite powder consisted of granules with an average size of $148 \mu \mathrm{m}$, made up of particles with an average size of $2.3 \mu \mathrm{m}$ (and narrow particle-size distribution). The granules were used to form cylindrical test specimens, $3 \mathrm{~mm}$ thick and $2 \mathrm{~cm}$ in diameter, by uniaxial pressing at 50,110, 120, 130, 140, and $300 \mathrm{MPa}$.

The specimens were sintered in air in an electric laboratory kiln using a three stages thermal cycle. In the first stage, or preheating stage (burnout of organic additives used in the compaction stage), heating was conducted at a rate of $12{ }^{\circ} \mathrm{C} / \mathrm{min}$ to a peak temperature of $400^{\circ} \mathrm{C}$ and $2-\mathrm{h}$ dwell at this temperature. In the second stage, or densification and grain-growth stage, heating was conducted at a rate of $12{ }^{\circ} \mathrm{C} / \mathrm{min}$ to a certain peak sintering temperature (hereafter sintering temperature) and dwell at this temperature for a certain period of time (hereafter sintering time). Finally, in the third stage, or cooling stage, cooling was done, from sintering to room temperature, at three different cooling rates: fast cooling (the specimens were withdrawn from the kiln and left to cool at ambient temperature), and 20 and $0.5^{\circ} \mathrm{C} / \mathrm{min}$. The sintering temperature of the specimens varied between 1000 and $1200{ }^{\circ} \mathrm{C}$ and the sintering time between 0 and 30-h.

Bulk density of the dry and sintered pieces was determined by the Archimedes method. The relative density $(\phi)$ of each ferrite specimen was calculated as the quotient of bulk density to true density.

\subsection{Characterization}

The cross-sectional area of the rectangular etched surface of each cylindrical sintered specimen was characterized using different techniques. Microstructure was observed in a scanning electron microscope (SEM), chemical composition was analysed by energy-dispersive X-ray (EDX) microanalysis (a technique that enables the average chemical composition of a surface area or a point chemical composition to be obtained), crystal structures were determined by X-ray diffraction (XRD), and the binding energy of the chemical bond for every chemical element — which depends on its coordination number (crystal field) and oxidation state- was determined by X-ray photoelectron spectroscopy (XPS) using non-monochromatic AlK $\alpha$ radiation $(1486.6 \mathrm{eV})$.

\section{RESULTS AND DISCUSSION}

Evolution of sintered relative density with dry relative density, at each studied cooling rate (fast cooling and cooling at 20 and $0.5^{\circ} \mathrm{C} / \mathrm{min}$ ), is shown in Fig. 1. Samples shown in this figure were fired at $1200{ }^{\circ} \mathrm{C}$ of peak sintering temperature and 2-h dwell time.

In the same manner, evolution of fired relative density with sintering time, at each studied sintering temperature $\left(1000,1025,1050,1075,1100,1150\right.$ and $\left.1200^{\circ} \mathrm{C}\right)$, is shown in Fig. 2. The samples shown in this figure had an initial dry relative density of 0.624 and, in this case, the cooling rate used in the thermal cycle was of $20^{\circ} \mathrm{C} / \mathrm{min}$.

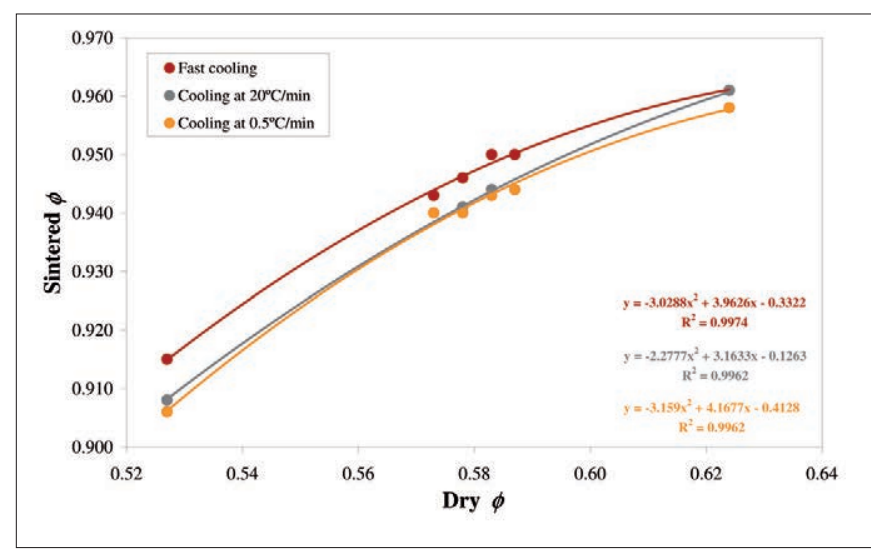

Fig. 1. Evolution of sintered relative density with dry relative density at each studied cooling rate (fast cooling, and cooling at 20 and $\left.0.5^{\circ} \mathrm{C} / \mathrm{min}\right)$.

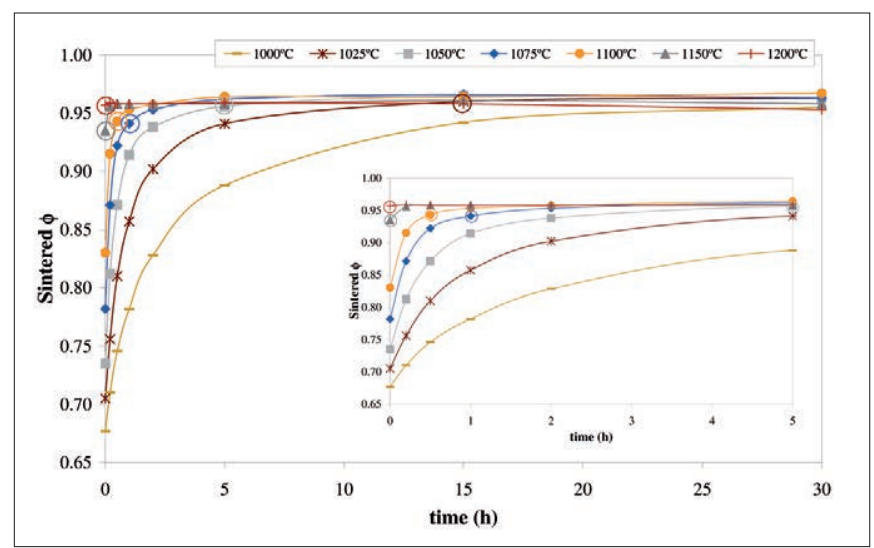

Fig. 2. Evolution of fired relative density with sintering time at each studied sintering temperature $(1000,1025,1050,1075,1100,1150$, and $\left.1200{ }^{\circ} \mathrm{C}\right)$.

\subsection{SEM results}

By way of example, Fig. 3 shows the cross-sectional microstructure (SEM micrographs) of the outermost and inner regions of the specimens, at each studied sintering time, at a sintering temperature of $1150{ }^{\circ} \mathrm{C}$.

Fig. 4 shows the evolution of the area occupied by crystal precipitates with tested dry relative densities at each studied cooling rate (fast cooling and cooling at 20 and $0.5^{\circ} \mathrm{C} / \mathrm{min}$ ). The sintered conditions for specimens of this figure are $1200{ }^{\circ} \mathrm{C}$ of peak sintering temperature and 2-h of sintering time. In the same way, Fig. 5 shows the evolution of the cross-sectional area occupied by crystal precipitates with sintering time at each 


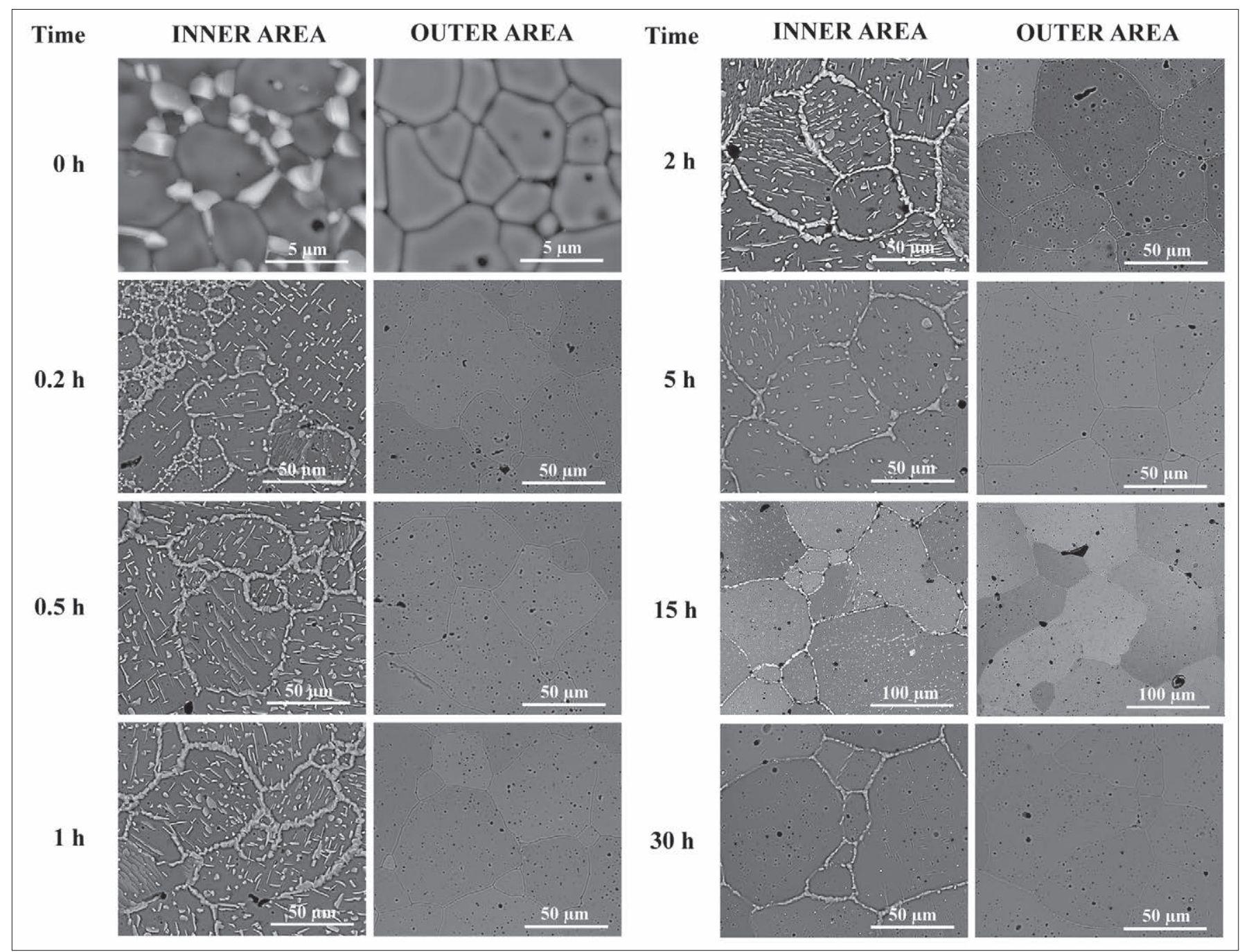

Fig. 3. Evolution of microstructure at the test sintering times at a sintering temperature of $1150{ }^{\circ} \mathrm{C}$.

studied sintering temperature $(1000,1025,1050,1075,1150$, and $\left.1200{ }^{\circ} \mathrm{C}\right)$. In the case of Fig. 5, all specimens had an initial dry relative density of 0.624 and the cooling rate used in the thermal cycle was $20^{\circ} \mathrm{C} / \mathrm{min}$. For both figures, the grater the dot density in the bars, the grater was the crystal density observed in the characterized sample.

The results shown in Figs. 3-5 allow the following conclusions to be drawn: (a) certain ferrite sintering conditions gave rise to crystal precipitates, though no crystal precipitates were detected at the lowest cooling rate $\left(0.5^{\circ} \mathrm{C} / \mathrm{min}\right)$ and the lowest sintering temperature $\left(1000^{\circ} \mathrm{C}\right)$. Crystal concentration and the area with the presence of crystals increased with dry relative density, cooling rate and sintering temperature, and increased with sintering time until a maximum value was reached. When sintering time was further prolonged, crystal concentration and the affected area decreased and some times even disappeared; (b) when the crystal concentrations increased the crystals occurred, first, at triple joint points, then on grain boundaries, and finally (when the triple joint points and grain boundaries had been saturated) inside the ferrite grains (see Fig. 6); (c) the highest concentration of crystal precipitates was observed in the inner area, whereas the lowest concentration was located in the outermost area, suggesting either that crystals precipitated from inside

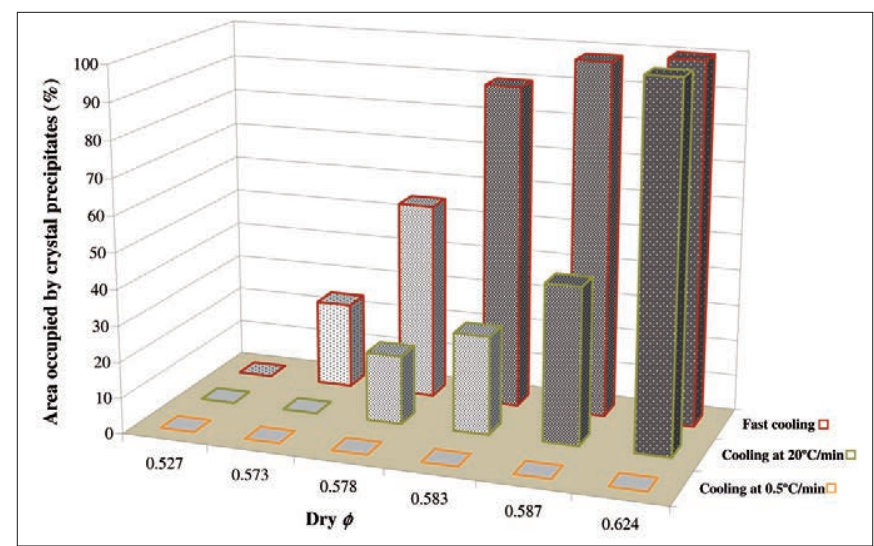

Fig. 4. Evolution of the cross-sectional area occupied by crystal precipitates with tested dry relative densities at each studied cooling rate (fast cooling, and cooling at 20 and $0.5^{\circ} \mathrm{C} / \mathrm{min}$ ).

outwards or that the crystal precipitates were removed, after precipitation, from the outermost area inwards; (d) rounded as well as needle-shaped crystal precipitates were observed (see Fig. 6), the rounded crystal precipitates being the first to occur at low crystal concentrations. When the crystal 


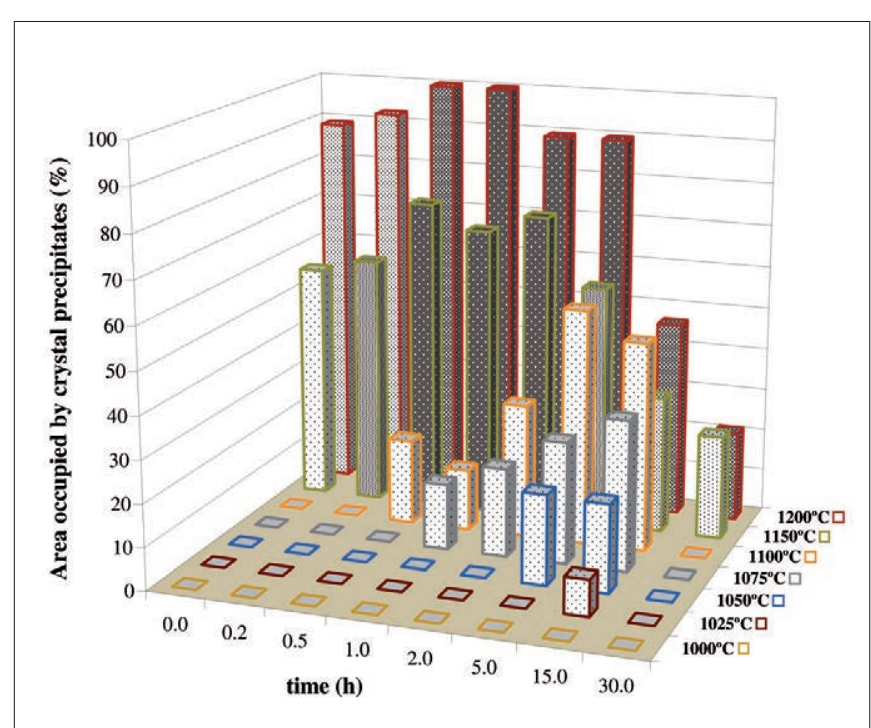

Fig. 5. Evolution of the cross-sectional area occupied by crystal precipitates with sintering time at each studied sintering temperature $\left(1000,1025,1050,1075,1100,1150\right.$, and $\left.1200{ }^{\circ} \mathrm{C}\right)$.

concentration subsequently increased (either by raising dry relative density, cooling rate, sintering temperature or prolonging sintering time, though always before the maximum sintering time), needle-shaped crystal precipitates began to be detected. The needle-shaped precipitates were located around the rounded precipitates and, when the surfaces of the latter had been saturated, inside the ferrite grains.

The occurrence and cross-sectional distribution of the crystal precipitates can be understood if the following explanation is accepted. Crystal precipitation occurred during the densification and grain-growth stages when these stages developed with an oxygen deficiency (as would be the case of pieces with a greater unfired relative density, in which the pore size distribution is finer and narrower and the network that forms between the particles is more tortuous, making access difficult). In addition, re-dissolution of the crystal precipitates might occur during the cooling stage if this stage is long enough to allow oxygen to enter the piece (the case of the lowest tested cooling rate). Dissolution depends on oxygen concentration and sintered relative density (the process proceeds from the outer area inwards, because the oxygen comes from the air; the process occurs more readily when dry relative density is lower, since the oxygen moves through the body by diffusion). In bodies with a small dry relative density, when low cooling rates were used no crystal precipitates appeared after the thermal cycle.

Crystal precipitates in the pieces increased with sintering temperature, which agrees with the $\mathrm{Fe}_{2} \mathrm{O}_{3}-\mathrm{ZnO}$ $\mathrm{NiO}$ ternary phase diagram shown in Fig. 9, and assuming that the behaviour of the $\mathrm{Fe}_{2} \mathrm{O}_{3}-\mathrm{ZnO}-\mathrm{NiO}-\mathrm{CuO}$ quaternary phase diagram, which is not available, have a similar behaviour of the ternary one. However, the evolution of crystal concentration with sintering time passed through a maximum. If the evolution of the relative density of the pieces sintered as a function of sintering time, shown in Fig. 2 , is compared with the evolution of the cross-sectional area occupied by crystal precipitates with sintering time (at each sintering temperature) depicted in Fig. 5, it may be observed that, at each tested temperature, the time at which crystal precipitates begin to be detected corresponds to relative densities of about 0.95 . This indicates that the influence of sintering time on the crystal precipitate concentration also stemmed from the oxygen concentration in the sample. At sintering onset the porosity of the piece was greater, its porous structure being less tortuous and more accessible from outside, which assured a continuous oxygen inflow into the piece. As the sintering stage advanced, the porosity of the piece decreased, the piece shrank, and the tortuosity of the porous structure increased, leaving isolated pores inside it. This new structure made it difficult for oxygen to enter the inner region of the piece, causing crystal precipitation to begin in this inner region. However, when sintering time was long enough, oxygen was able to penetrate into the piece (by diffusion), starting the dissolution of the previously precipitated crystals and thus decreasing the crystal precipitate concentration in the piece, at sufficiently long times even re-dissolving these crystals completely (as occurred at a temperature of $1100^{\circ} \mathrm{C}$ ).

Needle-shaped crystals were observed to dissolve before the rounded ones.

\subsection{EDX, XRD, and XPS results}

In order to identify the nature of the crystal precipitates detected by SEM, three experimental techniques were used:

\subsubsection{ENERGY-DISPERSIVE X-RAY (EDX) MICROANALYSIS}

Cross-sectionalSEM micrographs, at two magnifications, showing microstructure, grain boundaries and crystal precipitates morphology of a sintered specimen with crystal precipitates are shown in Fig. 6. Three different regions may be distinguished in this figure, which have been labelled as follows: (a) 'r1' (dark grey) ferrite matrix; (b) 'r2' (light-coloured) rounded crystal precipitates located on the grain surface, on the grain boundaries, and at triple joint points; (c) 'r3' (lighter-coloured than the r2 crystal precipitates) needle-shaped crystal precipitates located on the grain surface and around $\mathrm{r} 2$ crystal precipitates.

Fig. 7 presents the semi-quantitative average chemical composition of two sintered specimens, without and with crystal precipitates, and also the semi-quantitative point chemical composition of the ' $r 1$ ', ' $r 2$ ' and ' $r 3$ ' regions. As it can been seen, the average chemical composition of specimens without and with crystal precipitates is very similar to the chemical composition of the ferrite powder, but in the case of the specimen with crystal precipitates, a small increase in the $\mathrm{Zn}$ peak is to be noted. The point chemical composition of the ' $r 1$ ' area is also similar to the average chemical composition of the specimen without crystal precipitates and to that of the ferrite powder. The point chemical composition of the ' $r 2$ ' crystal precipitates displays a very significant increase in the $\mathrm{Zn}$ peak, while the point chemical composition of the ' $r 3$ ' crystal precipitates exhibits a very important rise in the $\mathrm{Cu}$ peak. These results suggest that the ' $\mathrm{r} 2$ ' crystal precipitates are zinc oxide crystals, and the ' $r 3$ ' crystal precipitates are copper oxide crystals.

\subsubsection{X-RAY DIFFRACTION (XRD) ANALYSIS}

The sintered specimens were analysed by $X$-ray diffraction in order to determine the crystalline structure of the crystal 

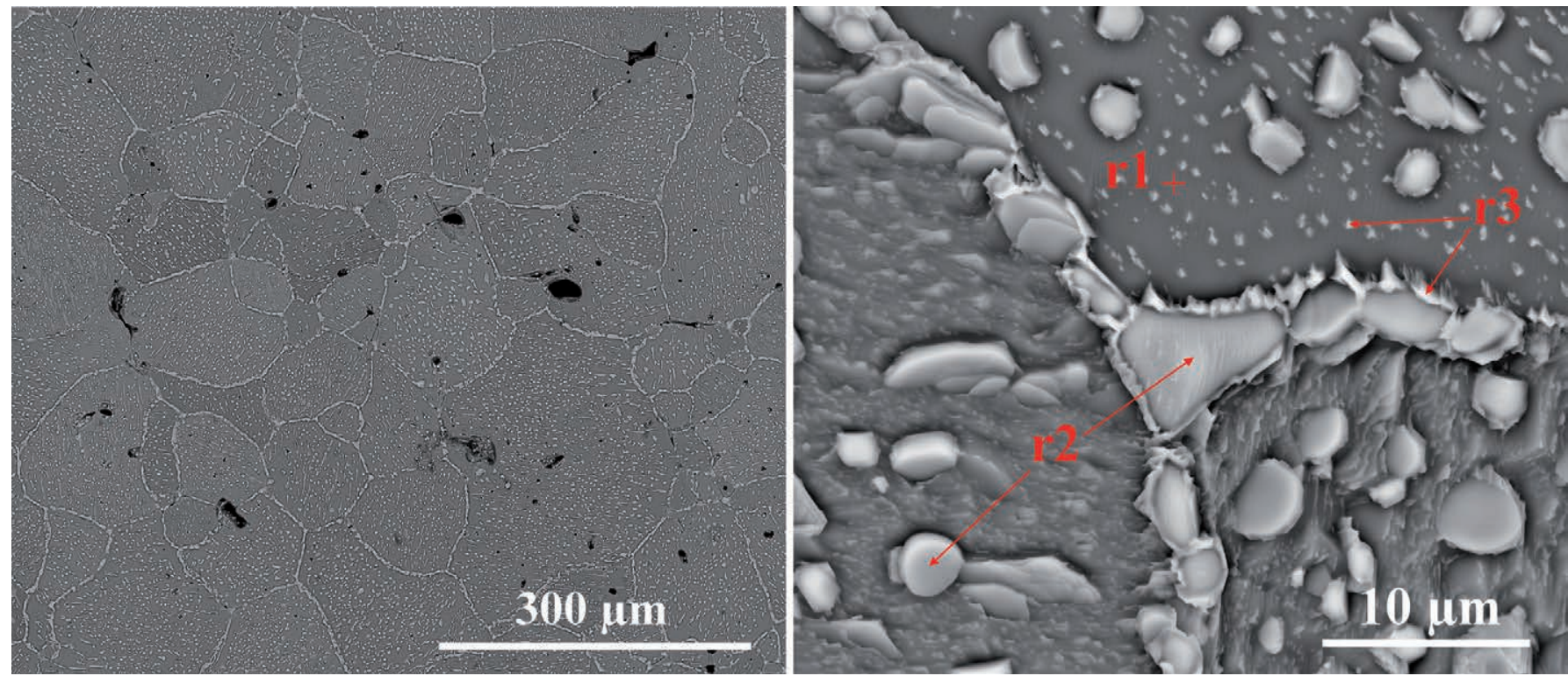

Fig. 6. Cross-sectional SEM micrograph at two magnifications showing the microstructure, grain boundaries and crystal precipitates morphology of a sintered specimen with crystal precipitates.

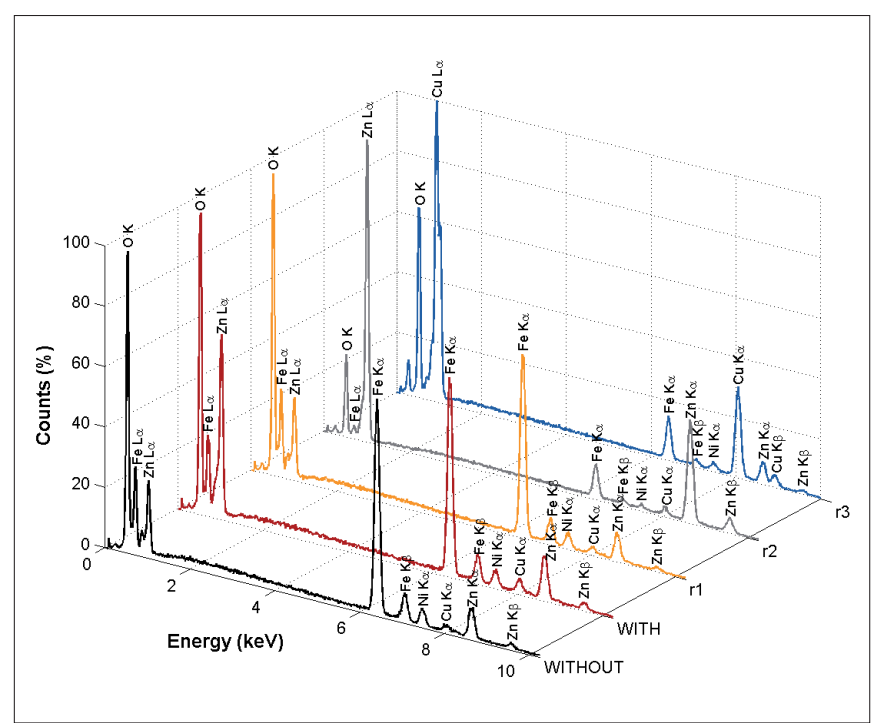

Fig. 7. Average chemical composition of two specimens, without and with crystal precipitates, and point chemical composition of the regions r1, r2 and r3 shown on Fig.6.

precipitates. X-ray diffraction of the cross-sectional area of the rectangular etched surface (containing crystal precipitates) allowed two crystal structures to be identified: franklinite (corresponding to the $\mathrm{ZnFe}_{2} \mathrm{O}_{4}$ ferrite) and zincite (corresponding to $\mathrm{ZnO}$ ). The zincite structure agrees with the EDX results of the ' $r 2$ ' crystal precipitates, which occurred particularly in the inner area. No crystal structure corresponding to the ' $\mathrm{r} 3$ ' crystal precipitates was identified, however, probably because the ' $\mathrm{r} 3$ ' crystal concentration was lower than the ' $\mathrm{r} 2$ ' crystal concentration.

\subsubsection{X-RAY PHOTOELECTRON SPECTROSCOPY (XPS) ANALYSIS}

Fig. 8 shows the peaks (including the Auger peaks) of XPS spectra of cross-sections of two sintered specimens, without and with crystal precipitates. The higher intensity

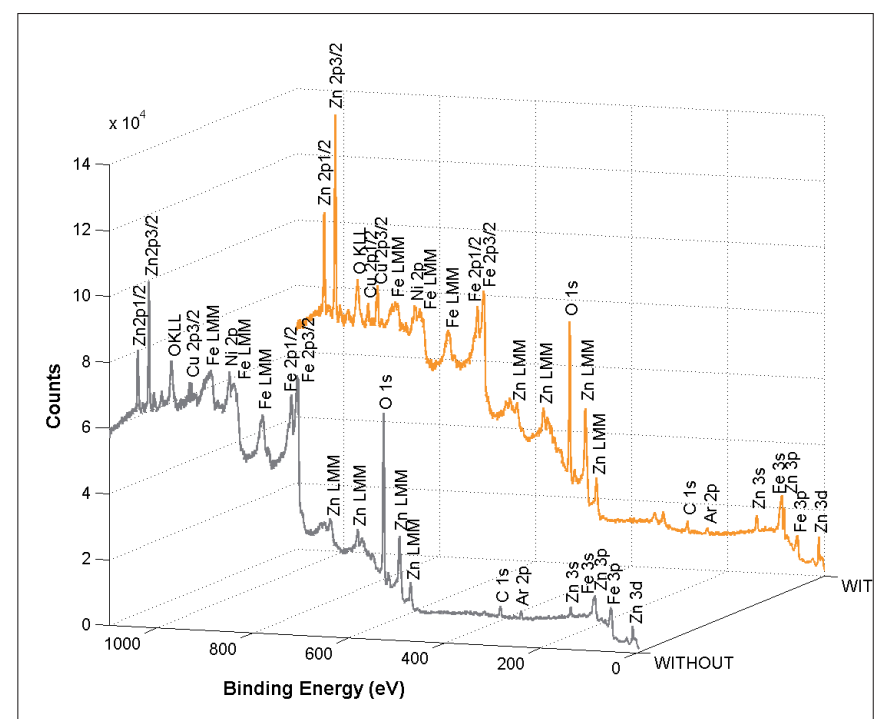

Fig. 8. Cross-sectional XPS spectra of two sintered specimens, without and with crystal precipitates.

peaks, corresponding to $\mathrm{Zn} 2 \mathrm{p}, \mathrm{Zn} \mathrm{LMM}, \mathrm{Cu} 2 \mathrm{p}$, Ni $2 \mathrm{p}$, $\mathrm{Fe} 2 \mathrm{p}$, and $\mathrm{O} 1 \mathrm{~s}$, were chosen in order to try to differentiate the two specimens (the area enclosed by each peak was quantified, taking into account the sensitivity factors proposed by the CasaXPS software for data treatment ${ }^{11-12}$ ). As it can be observed in this figure, zinc and copper contents are higher in the specimen cross-section containing crystal precipitates than in that without crystal precipitates, resulting in a $4.1 \mathrm{~mol} \%$ $\mathrm{Cu}$ and $17.2 \mathrm{~mol} \% \mathrm{Zn}$ in the sample with crystal precipitates versus a $1.3 \mathrm{~mol} \% \mathrm{Cu}$ and $10.8 \mathrm{~mol} \% \mathrm{Zn}$ in the sample without crystal precipitates.

The XPS spectrum of the specimen without crystal precipitates was considered to be representative of the binding energies of the chemical bonds in the ferrite structure involved in this study. The differences between the XPS spectrum of the specimen without crystal precipitates and the XPS spectrum 
of the specimen with crystal precipitates (especially in the highest peaks) are thus presumably due to the occurrence of crystal precipitates.

In the case of the peaks corresponding to the $\mathrm{Ni} 2 \mathrm{p}$ and Fe $2 p$ binding energies, there are no significant differences between the spectra, probably because $\mathrm{Ni}$ and $\mathrm{Fe}$ were only present in the ferrite structure and not in the crystal precipitates.

In the case of the peak corresponding to $\mathrm{Cu} 2 \mathrm{p}$ binding energy, the binding energy corresponding to copper in the ferrite structure appears in both spectra. However, the spectrum of the specimen with crystal precipitates also exhibits peaks corresponding to the $\mathrm{Cu}-\mathrm{O}$ chemical bond in $\mathrm{CuO}$ (the typical shake-up may even be distinguished) and, probably, in $\mathrm{Cu}_{2} \mathrm{O}$. The deconvolution of the $\mathrm{Cu} 2 \mathrm{p}$ binding energy in the specimen with crystal precipitates can be done considering three contributions: copper in ferrite (46.4 mol\%), cupric oxide- $\mathrm{CuO}(32.2 \mathrm{~mol} \%)$, and cuprous oxide- $\mathrm{Cu}_{2} \mathrm{O}(21.4$ $\mathrm{mol} \%$ ).

The peak corresponding to $\mathrm{Zn} 2 \mathrm{p}$ binding energy displays higher intensity in the specimen with crystal precipitates and is slightly shifted to the right (higher binding energy), probably due to the occurrence of the $\mathrm{Zn}-\mathrm{O}$ bond in the ferrite as well as in the zinc oxide, this result been even more obvious in the $\mathrm{Zn}$ LMM kinetic energy range (Auger peaks). The deconvolution of the $\mathrm{Zn} 2 \mathrm{p}$ binding energy in the specimen with crystal precipitates can be done considering two contributions: zinc in ferrite $(38.9 \mathrm{~mol} \%)$ and zinc in zinc oxide- $\mathrm{ZnO}(61.1 \mathrm{~mol} \%)$.

The peak corresponding to $\mathrm{O} 1 \mathrm{~s}$ binding energy shifts when crystal precipitates appear. For the deconvolution of $\mathrm{O} 1 \mathrm{~s}$ binding energy two contributions need to be considered in the specimens without crystal precipitates to explain the two different (octahedral and tetrahedral) sites defined by the oxygen network. In the specimens with crystal precipitates, an additional contribution needs to be considered, which again confirms the occurrence of copper and zinc oxides together in the ferrite structure. In the case of specimens with crystal precipitates the atomic composition of $\mathrm{O}$ is of $22.6 \mathrm{~mol} \%$ in crystal precipitates and $77.4 \mathrm{~mol} \%$ in ferrite.

The deconvoluted curves allow to obtain the atomic composition of the crystal precipitates (12.7 mol\% O, 10.5 $\mathrm{mol} \% \mathrm{Zn}$, and $2.2 \mathrm{~mol} \% \mathrm{Cu}$ ) and the matrix ferrite $(43.5 \mathrm{~mol} \%$ O, $20.1 \mathrm{~mol} \% \mathrm{Fe}, 6.7 \mathrm{~mol} \% \mathrm{Zn}, 2.4 \mathrm{~mol} \% \mathrm{Ni}$, and $2.0 \mathrm{~mol} \% \mathrm{Cu}$ ). In view of the position (binding energy) of the peaks used for deconvolution, the crystal precipitates probably contain $\mathrm{ZnO}$, $\mathrm{CuO}$, and $\mathrm{Cu}_{2} \mathrm{O}$. Zinc oxide may be estimated at about $24 \mathrm{wt} \%$, cupric oxide at about $3 \mathrm{wt} \%$, cuprous oxide at about $2 \mathrm{wt} \%$, and ferrite at about $71 \mathrm{wt} \%$.

\subsection{Comments}

Majima et al. ${ }^{13-15}$ reported that, under certain conditions, $\mathrm{ZnO}$ crystal precipitates can occur when $\mathrm{Ni}-\mathrm{Zn}$ ferrites are sintered. Authors noted the occurrence of crystals precipitates along the grain boundaries, especially at the triple points, being this process very sensitive to ferrite composition, sintering temperature and sintering atmosphere. They detected no crystal precipitates in specimens sintered in oxygen atmosphere, whereas samples sintered in air atmosphere, in fact, contained crystal precipitates.

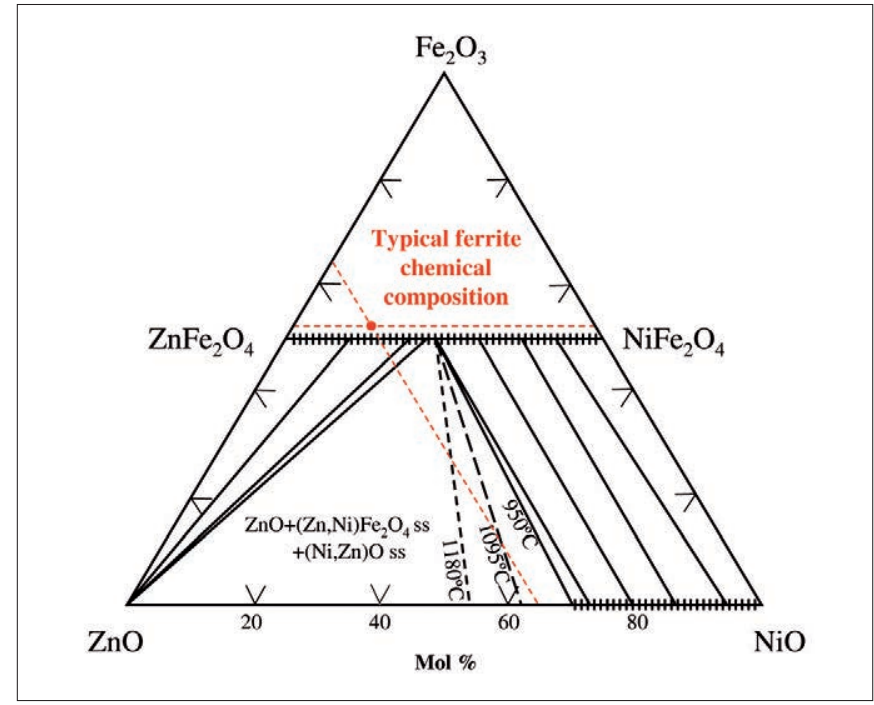

Fig. 9. $\mathrm{Fe}_{2} \mathrm{O}_{3}-\mathrm{ZnO}-\mathrm{NiO}$ phase diagram $\left(950-1180^{\circ} \mathrm{C}\right)$ showing the typical ferrite chemical composition (red dot).

In the present study it was confirmed again ${ }^{10}$ that cooling speed has a marked influence on the occurrence of crystal precipitates, affecting the kinetics of the precipitation process, while oxygen concentration was also found to have a determining influence on the formation of crystal precipitates. It was also ratified ${ }^{10}$ that higher dry relative density entails lower open porosity, leading to closed porosity in the first sintering stage. This closed porosity keeps oxygen from the air from entering the pores. Similarly, low cooling rates allow oxygen into the pores longer than fast cooling. Dry relative density and cooling rate are, therefore, both determining factors with relation to the presence of oxygen inside the pores.

The highlight from this study was that higher sintering temperature led to a higher occurrence and / or concentration of crystal precipitates, affecting the thermodynamics of the system, while longer sintering time led to a higher occurrence and/or concentration of crystal precipitates, up to a maximum; beyond this time, larger increments of time gave rise to a lower occurrence and/or concentration of crystal precipitates, as previously discussed from the results of SEM and the explanation to Fig. 5. Sintering t emperature and sintering time (as well as dry relative density and cooling speed ${ }^{10}$ ) must have a marked influence on the occurrence of crystal precipitates. The results in the present study are consistent with $\mathrm{ZnO}$ and $\mathrm{CuO}$ precipitation (with the possible subsequent reductio $\mathrm{n}$ of $\mathrm{Cu}(\mathrm{II})$ to $\mathrm{Cu}(\mathrm{I})$ ) being largely dependent on the oxygen concentration in the pores. The following proposed chemical reactions ${ }^{10}$ could explain again this dependence:

$$
\begin{aligned}
& {\left[\mathrm{Cu}_{0.12} \mathrm{Ni}_{0.23} \mathrm{Zn}_{0.65}\right] \mathrm{Fe}_{2} \mathrm{O}_{4}(\mathrm{~s}) \rightleftarrows} \\
& {\left[\mathrm{Cu}_{(0.12-\mathrm{x})} \mathrm{Ni}_{0.23} \mathrm{Zn}_{(0.65-\mathrm{y})}\right] \mathrm{Fe}_{2} \mathrm{O}_{(4-\mathrm{x}-\mathrm{y})}(\mathrm{s})+\mathrm{xCuO}(\mathrm{s})+\mathrm{yZnO}(\mathrm{s})}
\end{aligned}
$$

The quaternary phase diagram would explain the marked dependence of reaction (1) on composition and temperature (just as Fig. 9 explains this dependence in the case of $\mathrm{Ni}-\mathrm{Zn}$ ferrites ${ }^{16}$ ). Reaction (1) is also consistent with the experimental data obtained in this study and those reported in the literature ${ }^{13-15}$. 
The $\mathrm{CuO}$ obtained in reaction (1) is unstable at high temperatures, as reported in the traditional chemical literature $^{17-18}$, and decomposes as follows:

$$
2 \mathrm{CuO}(\mathrm{s}) \rightleftarrows \mathrm{Cu}_{2} \mathrm{O}(\mathrm{s})+\frac{1}{2} \mathrm{O}_{2}(\mathrm{~g})
$$

the equilibrium constant being:

$$
\mathrm{K}_{\mathrm{p}}=\sqrt{\mathrm{p}_{\mathrm{O}_{2}}}\left(\mathrm{~atm}^{1 / 2}\right)
$$

Reactions (1) and (2) are consecutive, the latter affecting the equilibrium of the former. Ferrite decomposition according to reaction (1) could be minimized by controlling initial composition and sintering temperature. Reaction (2) would be less important if there was a gas phase with a higher oxygen content.

Consequently, zinc and copper oxide crystal precipitate formation could be due to the sintering process being faster than oxygen diffusion from outside into the pores. The absence of oxygen inside the pores leads to the proposed chemical reactions, producing bulk precipitation of $\mathrm{ZnO}$ and $\mathrm{CuO}$ and transformation of $\mathrm{CuO}$ to $\mathrm{Cu}_{2} \mathrm{O}$. At the end of the densification and grain-growth stage, and in the cooling stage, the proposed chemical reactions could shift to the left, depending on the oxygen entering the pores. This process becomes more important when specimen porosity is high enough, thermal cycle is long enough and/or cooling speed is low enough to allow oxygen diffusion in all cases, even though the diffusion coefficient is small. The net effect is re-dissolution of crystal precipitates in the ferrite crystal structure, proceeding from the outermost area inwa rds.

\section{CONCLUSIONS}

The results obtained in this study suggest that the precipitation of zinc oxide $(\mathrm{ZnO})$ and copper oxide $(\mathrm{CuO}$ and $\mathrm{Cu}_{2} \mathrm{O}$ ) crystals during the sintering of copper-nickel-zinc ferrites occurred during the densification and grain-growth stages when these stages developed with an oxygen deficiency, which depended on the microstructure of the piece. Thus, when the pore size distribution was finer and narrower and the network that formed between the particles was more tortuous, making it difficult for oxygen to enter, the oxygen concentration inside the piece decreased leading to precipitation of the studied crystals. However, the results obtained also suggest that the partial or total dissolution of these crystal precipitates could also occur during the cooling stage, provided that this stage was long enough to allow oxygen to enter the piece.

\section{ACKNOWLEDGEMENTS}

The study has been conducted with funding from the project P1-1B2012-13, in the frame of the Jaume I University Plan to Promote Research 2012.

\section{REFERENCES}

1. Barba A, Clausell C, Felíu C, Monzó M., Sintering of $\left(\mathrm{Cu}_{0.25} \mathrm{Ni}_{0.25} \mathrm{Zn}_{0.50}\right) \mathrm{Fe}_{2} \mathrm{O}_{4}$ ferrite, J Am Ceram Soc, 87(4), 571-577 (2004)

2. Barba A, Clausell C, Monzó M, Jarque JC. Ciclo térmico para la obtención de una ferrita de Ni-Zn (I). Diseño de la etapa de sinterización. Bol Soc Esp Ceram Vidr, 47(1), 13-23 (2008).

3. Barba A, Clausell C, Monzó M, Jarque JC. Ciclo térmico para la obtención de una ferrita de Ni-Zn (II). Influencia de la etapa de enfriamiento. Bol Soc Esp Ceram Vidr, 47(2), 101-104 (2008).

4. Clausell C. Sinterización en fase sólida de una ferrita de Cu, Ni, Zn: estudio de la cinética del proceso del desarrollo microestructural y de la permeabilidad magnética. Doctoral dissertation. Universitat Jaume I, Castellón (2008).

5. Domenichini B, Caillot T. Sintering of $\mathrm{Fe}_{2} \mathrm{NiO}_{4}$ with an internal binder: a way to obtain a very dense material. Acta Materialia, 51, 4815-4821 (2003).

6. Rozman M, Drofenik M. Sintering of nanosized MnZn ferrite powders. Am Ceram Soc, 81(7), 1757-64 (1998).

7. Corso S, Tailhades P, Pasquet I, Rousset A, Laurent V, Gabriel A, Condolf C. Preparation conditions of pure and stoichiometric $\mathrm{Ni}_{x} \mathrm{Fe}_{3-x} \mathrm{O}_{4}$ bulk ceramics. Solid State Sci, 6, 791-798 (2004).

8. Akther Hossain AKM, Rahman ML. Enhancement of microstructure and initial permeability due to $\mathrm{Cu}$ substitution in $\mathrm{Ni}_{050-x} \mathrm{Cu}_{\times} \mathrm{Zn}_{050} \mathrm{Fe}_{2} \mathrm{O}_{4}$ ferrites. J Mag Mag Mat, 323, 1954-1962 (2011).

9. Mürbe J, Töpfer J. Low temperature sintering of sub-stoichiometric Ni-CuZn ferrites: shrinkage, microstructure and permeability. J Mag Mag Mat, 324, 578-583 (2012).

10. Barba A, Clausell C, Jarque JC, Monzó M. ZnO and CuO crystal precipitation in sintering $\mathrm{Cu}$-doped $\mathrm{Ni}$ - Zn ferrites. I. Influence of dry relative density and cooling rate. J Eur Ceram Soc, 31, 2119-2128 (2011).

11. Wagner CD, Riggs WM, Davis LE, Moulder JF, Muilenberg GE. Handbook of X-ray Photoelectron Spectroscopy. Perkin-Elmer Corporation and Physical Electronics Division (1979).

12. Moulder JF, Stickle WF, Sobol PE, Bomben KD. NIST X-ray Photoelectron Spectroscopy Database. Physical Electronics, Inc., Minnesota (USA) (1995).

13. Majima K, Hasegawa M, Katsuyama S, Nagai H, Mishima S. ZnO precipitation during sintering of NiZn ferrite used for the substrate of thinfilm heads. J Mater Sci Lett, 12, 185-187 (1993).

14. Majima K, Hasegawa M, Yokota M, Mishima S, Nagai H. Microstructural control of Ni-Zn ferrites for thin film heads. Materials transactions, JIM, 34 (6), 556-562 (1993).

15. Majima K, Hasegawa M, Katsuyama S, Mishima S, Nagai H. Influence of composition and oxygen partial pressure in sintering atmosphere on microstructure and magnetic properties of $\mathrm{Ni}-\mathrm{Zn}$ ferrite for thin film magnetic recording heads. Materials Transactions, JIM, 36 (11), 1392-1397 (1995).

16. Yamaguchi T, Takei T. Phase diagram and dissociation characteristics in the ferrite region of the system $\mathrm{Zn}-\mathrm{Fe}-\mathrm{O}$ in oxygen pressure of the atmosphere. Sci Paper Inst Phys Chem Res, 53 (1517), 207-215 (1959).

17. Cotton FA. Advancesd Inorganic Chemistry. John Wiley \& Sons Corporation, New York, 1999, pp. 856-867.

18. Massey AG, Thompson NR, Johnson BFG, Davis R. The Chemistry of Copper, Silver and Gold. Pergamon Texts in Inorganic Chemistry, Oxford, 1973.

Recibido: 22/01/2013

Recibida versión corregida: 14/01/2014

Aceptado: 10/03/2014 